\title{
Increase Sleep Quality with Massage's Therapy on Infant Aged 3-6 Months
}

\author{
Nurry Ayuningtyas Kusumastuti* \\ Midwifery Program Study, STIKes Yatsi Tangerang, Indonesia \\ *Corresponding Author: Nurry Ayuningtyas Kusumastuti, Midwifery Program Study, STIKes Yatsi Tangerang, Indonesia.
}

Received: August 19, 2019; Published: September 27, 2019

DOI: 10.31080/ASPE.2019.02.0154

\begin{abstract}
Background: The right massage's method on infant beneficial for increasing sleep quality. Infant 3 month old are able to receive stimulation and touch to develop their body. Along with the baby ages, the strength of muscles will increase. Massage's therapy regularly and continously would strengthen the connection between nerves that formed in order to develop brain function because development of brain cells is very rapid in this ages. This study aimed to determine increase sleep quality with massage's therapy among infant aged 3-6 months.

Subjects and Method: This was a quasy experiment with total 60 infants conducted in Clinic A, Tangerang. That was conducted from March 11 to April 26, 2019. Sample in this research were 30 baby's in intervention group with massage's therapy and 30 baby's in control group without massage's therapy. Massage's therapy as the independent variable and sleep quality as the dependent variables. The data was collected by using brief infant sleep questionnaire (BISQ). The distribution of the data was not normal, so bivaraite analysis using Mann-Whitney test.

Results: Infants in the intervention group by massage's therapy had mean $=1.83 ; \mathrm{SD}=1.80$ while infants without massage's therapy had mean $=0.30 ; \mathrm{SD}=0.95$. That indicated that there was increased average sleep quality's score after baby's got massage's therapy. P-value $<0.000$ it was indicated that there was increased slept quality with massage's therapy on infant aged 3-6 months.

Conclusions: Massage's therapy is effective to increase sleep quality, in infants aged 3-6 months.
\end{abstract}

Keywords: Massage's Therapy; Sleep Quality; Infants

\section{Background}

There are two kind of touch, that is passive and active. Passive touch like feeding, handling, kangaroo care, or changing the diapers for infant. Active touch involving massage's therapy. The right massage's method for infant is useful for increasing the sleeping quality. Baby very need sensation of touch in the beginning of a their life to adapt to his environment. The brain of infant twice more active than toddler $[1,2]$.

Monitoring and stimulating growth and development of infant is one of the assignment of midwives. It was appropriate of the Decree of the Minister of Health of the Republic of Indonesia Number 369/Ministry of Health/SK/III/2007 about Midwife Professional Standards. Massage's therapy is one suggest of stimulation for infant that developed in stimulating growth and development [3].

Infancy happens very quickly and could not be repeated, so its called golden age. In additional, called a critical period because the baby is very sensitive, so to support the process of growth and development must need requires adequat nutrition, good stimulation, and depend to surrounding environment. At this time, the brain development of babies who have plasticity will continue [4].
The first infant massage was introduced in China in second century BC. Infant massage has more beneficial among of weight gain, better sleep-wake pattern, enhanced neuromotor development, better emotional bounding attachment, reduce rates of nosocomial infection and thereby, reduce mortality in infant born preterm [5].

Babies need some adaptation because their body still weak. So, the adaptation of babies more importance for development and make their good behavior for prevent from the fatal consequence, that is death. Babies who can't calm himself to fall asleep would be crying, so it takes the appropriate handling to help them asleep $[1,5]$.

Infant 3 month old are able to receive stimulation and touch to develop their body. Along with the baby ages, the strength of muscles will increase. Massage's therapy regularly and continously would strengthen the connection between nerves that formed in order to develop brain function because development of brain cells is very rapid in this ages [6].

Sleep well is the most importance for growth and development babies cause while sleep the baby's brain would reach its peak. In 
addition while the babies sleep would produces three times more growth hormone than when the baby is awake. Growth and development of infant would be achieved optimally and the body able to repair and renew cells in the body when babies sleep longer [7-9].

Pattern of baby's sleep usually appear on infant ages 3-4 months. Habit of the babies on infant ages 3 months use along the night to sleep amount seventy percent, ages 6 months amount $85 \%$, and $90 \%$ in the end of first year of their life [1].

Massage's therapy is needed for infants because many beneficial of it, include stimulation of circulatory and gastrointestinal systems, increase weight gain, positive effects on neurogical and neuromotor development, and increase sleep quality. Massage was created many century ago. Indeed, already done since the beginning of life [5].

The purpose of this study was to analyze increasing sleep quality with massage's therapy in infants aged 3-6 months.

\section{Subjects and Method}

This was a quasy experiment at Clinic A Tangerang from March 11 to April 26, 2019. Population in this research was all infant aged 3-6 months in Clinic A Tangerang was 154 infants health and has not physical defect. Subjects in this study used simple random sampling were 30 infants received massage's therapy and 30 infants without massage's therapy. The subjects did was pre test and post test in each group.

Measuring instrument for sleeping quality used BISQ questionnaire. The data were analyzed by Mann Whitney test because this data used numeric variable, not normally distributed, and two group unpaired.

\section{Results}

Study subjects characteristics

The results of the characteristics of the study subjects in table 1 show that there are 30 sample in the intervention group that get massage's therapy and 30 in control groups with no massage's therapy. The description of study variables is explained based on characteristics, criteria, frequency, and percentage.

Baby's characteristics in this study most babies aged 3 months in the intervention group 14 babies (46.7\%) with massage's therapy and also in the control group 18 babies (60\%) without massage's therapy. All of them was healthy 30 infants $(100 \%)$ in each group. Most gender in this study were female in the intervention group of 22 infants $(73.3 \%)$ with massage's therapy and the control group of 20 infants $(66.7 \%)$ without massage's therapy. The most status of babies were the second child of 13 babies (43.3\%) in intervention group, likewise in control group.
Mother's characteristics in this study were the most mother's that the babies got massage's therapy were 25 mothers (83.3\%) and the mother's that the babies did not got massage's therapy was 28 mothers (93.3\%). Mothers were mostly housewife, that were 25 mothers (83.3\%) in each group. Level of family income showed that with $\geq$ minimum regional wage were 27 mothers $(90 \%)$ in intervention group and in the control group $<$ minimum regional wage were 24 mothers $(80 \%)$ in control group. Most of mothers were graduated from senior high school, that was 19 mothers (63.3\%) in intervention group and 18 mothers (60\%) in control group.

\section{Bivariate analysis}

Bivariate analysis explain independent variable in this study is massage's therapy and dependent variable is sleeping quality. The method in this study used is Mann Whitney test because the distribution of the data was not normal. Based on the Mann Whitney Test different test on sleep quality, it showed that $\mathrm{p}<0.000$ and it means that there were significant differences between massage's therapy with sleep quality in the intervention group and the control group.

\section{Discussions and Conclusion}

Increase sleep quality with massage's therapy in infants aged 3-6 months old

The result of this study explain that massage's therapy in infants aged 3-6 month had more slept better than infants without massage's therapy. It showed that massage's therapy increased sleep quality from pre test before got massage's therapy in intervention group with after infants got massage's therapy in post test.

This was appropriated with a research by Shadik [10] which showed that infant massage can improved quality of sleep on infant aged 6-12 month old. The result tested by using Wilcoxon match pairs test that was $\mathrm{p}<0.005$. It was pre-experimental approach with one group pre-test post-test. The data was collected by quationnaire of Pittsburgh Sleep Quality Index (PISQ) with 30 babies. There was 10 infants had bad sleep quality (33\%) in pre test, after got intervention with baby massage in post test all of them (100\%) became had good sleep quality. So, there was an improvement in sleep quality.

Baby massage can be repair the blood circulation, so it useful to carry out the distribution of oxygen and nutrition. Indirectly, that is provides an effect on the body's nerves and relaxation, so the baby's body not only repair automatically, but also can do comprehensive treatment. Massage therapy produce pressure on certain part of their body, then produce the stimulation to nerves's system automatically. So, the body can do the best work. But, remember baby massage could not allow when the baby sleep, enforce and crying loudly, before and after eat or drink (Maharani, 2009). 


\begin{tabular}{|c|c|c|c|c|c|c|}
\hline Characteristics & Criteria & $\mathbf{n}$ & $\%$ & $\mathbf{n}$ & $\%$ & $\mathbf{p}$ \\
\hline Infants' Age & $\begin{array}{l}3 \text { months } \\
4 \text { months } \\
5 \text { months } \\
6 \text { months }\end{array}$ & $\begin{array}{c}14 \\
12 \\
4 \\
0\end{array}$ & $\begin{array}{c}46.7 \\
40 \\
13.3 \\
0\end{array}$ & $\begin{array}{c}18 \\
10 \\
1 \\
1\end{array}$ & $\begin{array}{c}60 \\
33.3 \\
3.3 \\
3.3 \\
\end{array}$ & 0.301 \\
\hline Status Kesehatan & $\begin{array}{l}\text { Healthy } \\
\text { Sick }\end{array}$ & $\begin{array}{c}30 \\
0\end{array}$ & $\begin{array}{c}100 \\
0\end{array}$ & $\begin{array}{c}30 \\
0\end{array}$ & $\begin{array}{c}100 \\
0\end{array}$ & 1 \\
\hline Jenis Kelamin & $\begin{array}{l}\text { Male } \\
\text { Female }\end{array}$ & $\begin{array}{c}8 \\
22\end{array}$ & $\begin{array}{l}26.7 \\
73.3\end{array}$ & $\begin{array}{l}10 \\
20\end{array}$ & $\begin{array}{l}33.3 \\
66.7\end{array}$ & 0.120 \\
\hline Status Bayi & $\begin{array}{l}\text { One } \\
\text { Two } \\
\text { Three } \\
\text { Others }\end{array}$ & $\begin{array}{c}10 \\
13 \\
5 \\
2\end{array}$ & $\begin{array}{c}33.3 \\
43.3 \\
16.7 \\
6.7\end{array}$ & $\begin{array}{c}8 \\
13 \\
6 \\
3\end{array}$ & $\begin{array}{c}26.7 \\
43.3 \\
20 \\
10\end{array}$ & 0.828 \\
\hline Umur Ibu & $\begin{array}{c}<20 \text { years } \\
20-35 \text { years } \\
\geq 35 \text { years }\end{array}$ & $\begin{array}{c}0 \\
25 \\
5\end{array}$ & $\begin{array}{c}0 \\
83.3 \\
16.7 \\
\end{array}$ & $\begin{array}{c}0 \\
28 \\
2\end{array}$ & $\begin{array}{c}0 \\
93.3 \\
6.7 \\
\end{array}$ & 0.651 \\
\hline Pekerjaan Ibu & $\begin{array}{c}\text { Civil Servant/Soldier } \\
\text { Entrepreneur Private } \\
\text { Housewife }\end{array}$ & $\begin{array}{c}2 \\
3 \\
0 \\
25 \\
\end{array}$ & $\begin{array}{c}6.7 \\
10 \\
0 \\
83.3 \\
\end{array}$ & $\begin{array}{c}3 \\
1 \\
1 \\
25 \\
\end{array}$ & $\begin{array}{c}10 \\
3.3 \\
3.3 \\
83.3 \\
\end{array}$ & 1.000 \\
\hline Tingkat Pendapatan & $\begin{array}{l}<\text { Minimum wage } \\
\geq \text { Minimum wage }\end{array}$ & $\begin{array}{c}3 \\
27\end{array}$ & $\begin{array}{l}10 \\
90\end{array}$ & $\begin{array}{c}6 \\
24 \\
\end{array}$ & $\begin{array}{l}20 \\
80\end{array}$ & 0.647 \\
\hline Pendidikan Ibu & $\begin{array}{l}\text { PS graduate } \\
\text { JHS graduate } \\
\text { SHS graduate } \\
\text { D1-D3 graduate } \\
\text { D4/S1 graduate }\end{array}$ & $\begin{array}{c}1 \\
4 \\
19 \\
4 \\
2\end{array}$ & $\begin{array}{c}3.3 \\
13.3 \\
63.3 \\
13.3 \\
6.7\end{array}$ & $\begin{array}{c}1 \\
2 \\
18 \\
7 \\
1\end{array}$ & $\begin{array}{c}3.3 \\
6.7 \\
60 \\
23.3 \\
3.3\end{array}$ & 0.436 \\
\hline
\end{tabular}

Table 1: The Characteristics of Study Subjects.

\begin{tabular}{|l|c|c|c|c|c|}
\hline \multicolumn{1}{|c|}{ Variable Group } & n & Mean & Median & SD & p \\
\hline Sleeping quality & & & & & \\
\hline Massage & 30 & 5.63 & 5.00 & 1.71 & 0.632 \\
No massage & 30 & 5.77 & 6.00 & 1.92 & \\
\hline
\end{tabular}

Table 2: Mann Whitney test variable sleep quality and no massage before treatment.

\begin{tabular}{|l|c|c|c|c|c|}
\hline Variable Group & $\mathbf{n}$ & Mean & Median & SD & $\mathbf{p}$ \\
\hline Sleeping quality & & & & & \\
\hline Massage & 30 & 1.83 & 2.00 & 1.80 & $<0.000$ \\
\hline No massage & 30 & 0.30 & 0.00 & 0.95 & \\
\hline
\end{tabular}

Table 3: Mann-Whitney test variable difference in sleep quality with massage and no massage.

The study by Guyton [11] showed that the effect of baby massage to improve sleep quality. The intervention group with baby massage in pre-test there were 20 babies who needs an hour to fall asleep after awake. After they got baby massage in post test 29 babies who needs an hour to fall asleep after awake. Sleep on babies was highly important to determine the process of infant's development. Brain cells and growth hormone about $75 \%$ would increased while babies were sleeping.

Massage therapy stimulate to produce oxytocin and endorphins which would make an the discomfort. The effect of sleep less in babies could have a negative impact on the physical and cognitive development of the babies. That was an indicator of their health development, especially the ability to think for the future. So, massage therapy was recommended for increasing baby's sleep duration at aged 3-6 months and fall asleep after woke up.

Sleep needs for infants aged 1-18 months old between 12-14 hours/day and would produce a sufficient amount of serotonin. In addition, the infants who received massage's therapy mostly have a fast duration to fall asleep $[12,13]$.

Increasing level activity of neurotransmitter serotonin which produced during the massage caused by increased sleep duration 
in infants, so increasingly the capacity of receptor cells to bind the glucocorticoids and decreasing the levels of adrenaline (cortisol hormone) hormones. As the results the babies felt relaxed, more comfortable and calm while sleeping $[6,14]$.

The significant results showed on a study done by Field [15]. Infants of 68 preterm infants with 30 weeks gestational. It was randomly decided to two group, one group got moderate pressure massage therapy group and others got light pressure massage therapy group. Observation of behavior were made from sleep and wake of infant and behavior of stress. Heart rate of infant was recorded using electrocardiograms (EKG) before and during intervention of massage's therapy. Infants got 15 massage 3 times per day during 5 days and the treatment was 15 minutes periods after feeding. It was more significant moderate pressure than the light pressure massage. Moderate pressure massage gave more relaxed behavior states which could see from had deep sleep and less active sleep and effective than light pressure massage.

The results of study Yates [16] showed that massage's therapy is well tolerated in infants born preterm. In addition, the study of Kelmanson [17] showed that infants were born preterm, then got massage's therapy until aged 8 months old had better slept because reduced the frequencies of awakening and more easier to fall asleep after the babies woke up [18-29].

\section{Bibliography}

1. Guyton Hall. Proses Tidur. Jakarta: Rineka Cipta (2010).

2. Leonard J. "Exploring Neonatal Touch". Wesley Journal Psychology 3 (2008): 39-47.

3. Kepmenkes RI. The Baby Book: Everything Keputusan Menteri Kesehatan Republik Indonesia. Standar Profesi Bidan. Jakarta (2007).

4. Zero To Three. "Behaviour and Development". Washington DC: National Center for Infant, Toddlers and Families (2012).

5. Kulkarni Anjali., et al. "Massage and Touch Therapy in Neonates: The Current Evidence”. Indian Pediatrics 47 (2010).

6. Roesli U. Pedoman pijat bayi (2007).

7. Helen S., et al. "The Benefit of Baby Massage". Pediatric Nursing Journal 17 (2005).

8. Prasetyono DS. Buku Pintar Pijat Bayi. Yogyakarta: Buku Biru (2013).

9. Widiyanti M. Hubungan Pijat Bayi dengan Pola Tidur Bayi Usia 3-6 Bulan Di Bidan Praktek Swasta Ny. Numusriah Kota Kediri. Jurnal Kesehatan. 6 (2008): 79-83.
10. Shadik N. Pengaruh Pijat Bayi Terhadap Kualitas Tidur Bayi Usia 6-12 Bulan di Rumah Bersalin Rachmi Yogyakarta Tahun 2011. Yogyakarta: STIKES Aisyah (2011).

11. Guyton Hall. Buku Ajar Fisiologi Kedokteran. Edisi Sebelas. Jakarta: EGC (2007).

12. Harkreader H. Fundamental of nursing (3rd ed.). St. Louis Saunders: Courtesy Ballard Medical Products Draper UT (2007).

13. Rini. Panduan praktis Memijat Buah Hati Anda. Yogyakarta: Nusa Pressindo. Jakarta (2008).

14. Yahya N. SPA Bayi dan Anak. Solo: Metagraf (2011).

15. Field T., et al. "Moderate Versus Light Pressure Massage Therapy Leads to Greater Weight Gain in Preterm Infants". Infant Behavior and Development 29 (2006): 574- 578.

16. Yates Charlotte C., et al. "The Effect of Massage Therapy to Introduce Sleep in Infants Born Preterm". Pediatric Physical Therapy 26 (2014): 405-410.

17. Kelmanson IA and Adulas EI. "Massage Therapy and Sleep Behaviour in Infant Born with Low Birth Weight". Complementary Therapies in Clinical Practice 12 (2006): 200-205.

18. American Massage Therapy Association (AMTA). Massage therapy may benefit newborns (2008).

19. Amstrong T. "Smart Baby's Brain". Prestasi Pustakaraya: Jakarta (2003).

20. Kementerian Kesehatan Republik Indonesia. Pedoman Pelaksanaan Stimulasi, Deteksi Dan Intervensi Dini Tumbuh Kembang Anak di Tingkat Pelayanan Kesehatan Dasar. Jakarta: Kementerian Kesehatan Republik Indonesia (2009).

21. Instrument Stimulasi, Deteksi, dan Intervensi Dini Tumbuh Kembang Anak. Jakarta: Kementerian Kesehatan Republik Indonesia (2010).

22. Lestari Budi and Warsiti. "The Influences of Massage on Baby Towards the level of Sleep Fulfillment in 3 to 6 Months Infants in the Regency of Sentolo, Kulon Progo. Yogyakarta : STIKes Aisyiyah (2014).

23. Levy SE and Hyman SL. "Pediatric Assessment of The Child with Developmental Delay". Pediatric Clinics of North America 40 (1993): 465-477.

24. Pamela ME. Elements of Pediatric Physiotherapy, Churchill Livingstone (1993). 
25. Pedoman Pijat Bayi. Edisi Revisi. Jakarta: PT Trubus Agriwidia (2008).

26. Pedoman Pijat Bayi. Jakarta: Trubus Agriwidya (2009).

27. Pedoman Pijat Bayi. Jakarta: Pustaka Pembangunan Swadaya Nusantara (2013).

28. Ruffin PT. "A History of Massage in Pressure were More Likely to Improve Their Sleep Quality Compared to Infants who Got Baby Massage Therapy with Mild Massage Pressure". Nurse Training School Curricula (1860-1945). Journal Holistic Nurse 29 (2011): 61-67.

29. Sears W., et al. "The Baby Book". Jakarta: Serambi Ilmu Semesta (2008).

Volume 2 Issue 10 October 2019

(C) All rights are reserved by Nurry Ayuningtyas

Kusumastuti. 